\title{
The cycling behaviour of zinc electrodes in a nickel oxide-zinc accumulator
}

\author{
J. HENDRIKX*, W. VISSCHER, E. BARENDRECHT \\ Laboratory for Electrochemistry, Department of Chemical Technology, Eindhoven University of \\ Technology, PO Box 513, $5600 \mathrm{MB}$ Eindhoven, The Netherlands
}

Received 16 October 1984; revised 6 March 1985

The behaviour of porous zinc electrodes was investigated by monitoring the potential distribution along the surface of the electrode during charging and discharging in a nickel oxide-zinc battery. Impedance measurements of the zinc electrode were taken as a function of state-of-charge and of the cycle number. The composition of the electrode was varied with $\mathrm{HgO}$ and $\mathrm{PbO}$ additives. Shape change was observed for all electrodes. The observed potential distribution has led to the tentative explanation that the shape change phenomenon is caused by diffusion of zincate along the surface.

\section{Introduction}

Much of the development effort on aqueous electrolyte batteries is focused on batteries with zinc as negative electrode, e.g. the nickel oxidezinc system. Amongst the problems which hinder a breakthrough are shape change, densification, passivation and dendrite formation. Shape change is considered as the most important factor leading to limited battery life. Shape change involves the redistribution of the active material on the zinc electrode geometric area with cycling. The active material is removed from the electrode edges and agglomerates towards the plate centre. Many investigations have been carried out to regain a better understanding of this phenomenon. Parameters influencing shape change are:

i. the depth of discharge

ii. the type of separator

iii. the stoichiometric ratio of negative and positive active material

iv. the cell construction and

$\mathrm{v}$. additives to the zinc electrode.

Amalgamation of the zinc electrode increases the hydrogen overpotential and also increases the rate of shape change [1]. Other additives, however, (such as cadmium, lead and thallium, which also increase the hydrogen overpotential) reduce the rate of shape change $[2,3]$. Some surface-active agents, such as Emulphogene, have a positive effect upon the cycle life [4].

The effect of additives in pasted zinc battery electrodes has been studied in great detail by McBreen et al. [5-7]. They concluded [5] that the beneficial effect of some metal oxide additives $\left(\mathrm{PbO}, \operatorname{In}(\mathrm{OH})_{3}, \mathrm{Tl}_{2} \mathrm{O}_{3}\right.$ and mixtures of these) is due to the overpotential increase which improves the current distribution and so decreases the rate of shape change. They suggested that this additive effect is in reality a substrate effect and assumed that the adverse effect of $\mathrm{HgO}$ is due to a slight overpotential decrease. The effect on the current distribution during formation of the electrodes has been further investigated by means of a sectioned nickel oxide electrode [6]. In the case of zinc electrodes with no additive, the average current density at the edge sections was about twice that at the centre sections. However, in this latter investigation it was found that $\mathrm{HgO}$ had little effect on the current distribution which, of course, does not support the earlier findings. In addition, anomalous effects were found with $\mathrm{PbO}$ additives because of leaking of the additive into the electrolyte, especially at the electrode edge.

Two different mechanisms have been proposed to explain shape change: one based on

* Present address: AMP Holland, Rietveldehweg 32, 5222 AR's Hertogenbosch, The Netherlands. 
electro-osmosis (Choi et al. [8]) and the other on current distribution (McBreen [9]). Neither of these models can adequately and consistently describe the observed phenomena. In order to get more insight into the processes occurring at the zinc electrode of the nickel oxide-zinc battery, the behaviour of the zinc electrode was investigated by monitoring the potential distribution along the surface during cycling and by measuring the impedance both in charged and discharged state.

For a study of the shape change phenomenon it would be preferable to monitor the current distribution which gives direct information about the material distribution over the zinc electrode. However, it is not possible to carry out current distribution measurements via sectioning of the zinc electrode: the sections shortcircuit as a result of dendrite formation during charging. (Sectioning of the counter electrode would be possible but then it has to be assumed that the current flow through a section of the counter electrode is a good indication of the flow through the part of the zinc electrode just opposite that section.) For our experiments we have therefore decided to measure the potential distribution as this is experimentally easier to do.

The use of impedance techniques for the characterization of batteries is frequently advocated since it is, in general, a good diagnostic for assessing the state-of-charge. This study was carried out with self-built cells of about $0.5 \mathrm{~A} \mathrm{~h}$ capacity, subjected to repeated charge-discharge cycles. Because of the reported influence of amalgamation on the shape change [1-3], the effect of incorporating metal oxide additives $(\mathrm{HgO}, \mathrm{PbO})$ and of replacing zinc oxide partially by amalgamated zinc powder, was also studied.

\section{Construction of electrodes and cell design}

\subsection{Zinc electrode}

The following zinc electrodes were used: I. Teflon-bonded zinc oxide; II. Teflon-bonded zinc oxide with additive $(2 \mathrm{wt} \% \mathrm{HgO}$ or 2 wt \% PbO); III. One part Teflon-bonded zinc oxide (with $1-6 \mathrm{wt} \% \mathrm{HgO}$ as an additive) and two parts amalgamated zinc powder (with 1, 3 or $6 \mathrm{wt} \% \mathrm{Hg}$ ), the latter as furnished by Metallurgy Hoboken-Overpelt, Belgium. The Teflonbonded zinc oxide was prepared following the procedure given by McBreen and Gannon [5]: a $2 \mathrm{ml}$ portion of Teflon dispersion $(30-\mathrm{N}$, DuPont) was diluted with $15 \mathrm{ml}$ doubly distilled water and added to $25 \mathrm{~g}$ zinc oxide (Merck p.a.). The paste was then heated to $280-300^{\circ} \mathrm{C}$, cured at that temperature for about $1 \mathrm{~h}$ and then crushed. The Teflon-bonded zinc oxide was mixed thoroughly with $\mathrm{HgO}$ or $\mathrm{PbO}$ as an additive for preparing the type II electrode, or with $\mathrm{HgO}$ and amalgamated zinc powder for preparing the type III electrode. The electrodes themselves were prepared by pressing the mixture in a mould onto a nickel screen (which had been plated beforehand with silver and acted as a current collector; geometric surface area of $3.5 \times 3.9 \mathrm{~cm}$ ). The current lead of silver was connected to the screen by spotwelding. Table 1 gives the composition of the different zinc electrodes.

\subsection{Nickel oxide electrode}

Sintered nickel oxide electrodes were taken from commercial Ni-Cd batteries, Varta type SD 2.4. Each electrode $(3.5 \times 3.9 \times 0.085 \mathrm{~cm})$ had a capacity of $0.4 \mathrm{Ah}$. In cells 1 to 9 , the nickel oxide electrodes were uncharged and in cells 10 to 13 they were charged (about $0.3 \mathrm{~A} \mathrm{~h}$ ).

\subsection{Separator system}

The separator was a RAI P-2193 specimen $(0.009 \mathrm{~cm}$ thick $)$, consisting of one layer of cellophane sandwiched between two layers of RAI P-2291 (a copolymer of methacrylic acid and cross-linked low-density polyethylene). All experiments were carried out in $9.5 \mathrm{M} \mathrm{KOH} /$ $0.5 \mathrm{M} \mathrm{ZnO} / 0.5 \mathrm{M} \mathrm{LiOH}$ prepared from Analar chemicals and doubly distilled water. The reference electrode was a $\mathrm{Hg}-\mathrm{HgO}$ electrode in glass tubing.

\subsection{Cell specifications and assembly}

The cells were constructed of acrylic plastic with interior dimensions of $6 \times 3.7 \times 0.4 \mathrm{~cm}$. 
Table 1. Composition of zinc electrodes and assembly type of cells

\begin{tabular}{|c|c|c|c|c|c|c|c|c|}
\hline \multirow[t]{2}{*}{$\begin{array}{l}\text { Cell } \\
\text { no. }\end{array}$} & \multirow[t]{2}{*}{$\begin{array}{l}\text { Teflon-bonded } \\
\text { zinc oxide }(\mathrm{g})\end{array}$} & \multicolumn{2}{|c|}{ Additive } & \multicolumn{2}{|c|}{$\begin{array}{l}\text { Amalgamated } \\
\text { zinc powder }\end{array}$} & \multirow[t]{2}{*}{$\begin{array}{l}\text { Thickness } \\
\left(\mathrm{cm} \times 10^{3}\right)\end{array}$} & \multirow[t]{2}{*}{$\begin{array}{l}\text { Type of zinc } \\
\text { electrode }\end{array}$} & \multirow[t]{2}{*}{$\begin{array}{l}\text { Assembling } \\
\text { type }\end{array}$} \\
\hline & & Type & $(g)$ & (g) & $\% \mathrm{Hg}$ & & & \\
\hline 1 & 2.0 & - & - & - & - & $64 \pm 3$ & I & A \\
\hline 2 & 2.0 & $\mathrm{PbO}$ & 0.04 & - & - & $65 \pm 10$ & II & A \\
\hline 3 & 2.0 & $\mathrm{HgO}$ & 0.04 & - & - & $65 \pm 7$ & II & A \\
\hline 4 & 1.0 & $\mathrm{HgO}$ & 0.01 & 2 & 1 & $69 \pm 9$ & III & A \\
\hline 5 & 1.0 & $\mathrm{HgO}$ & 0.03 & 2 & 3 & $67 \pm 10$ & III & A \\
\hline 6 & 1.0 & $\mathrm{HgO}$ & 0.06 & 2 & 6 & $67 \pm 9$ & III & A \\
\hline 7 & 2.0 & $\mathrm{HgO}$ & 0.04 & - & - & $62 \pm 8$ & II & $\mathbf{B}$ \\
\hline 8 & 1.5 & $\mathrm{HgO}$ & 0.03 & - & - & $52 \pm 2$ & II & B \\
\hline 9 & 1.5 & - & - & - & - & $53 \pm 3$ & I & B \\
\hline 10 & 1.5 & - & - & & & - & I & B \\
\hline 11 & 2.0 & - & - & -.. & - & $69 \pm 5$ & I & A \\
\hline 12 & 2.0 & - & - & - & - & $66 \pm 8$ & I & A \\
\hline 13 & 2.0 & - & - & - & - & $65 \pm 5$ & I & A \\
\hline 14 & 2.0 & - & - & - & - & $66 \pm 5$ & I & A \\
\hline
\end{tabular}

Provisions were made for introduction of one or more reference electrode(s) by drilling holes (diameter $0.6 \mathrm{~cm}$ ) in the wall. The reference electrode compartment and the interior were connected by a drilled hole (diameter $0.1 \mathrm{~cm}$ ), filled with adsorber material to prevent bubbles entering. The RAI P-2193 separator was wrapped three times around the zinc electrode in such a way that short-circuiting was almost impossible. Furthermore, a non-woven propylene adsorber (RAI A-1480) was placed against the nickel oxide electrode. The cell was filled such that the level of the electrolyte was about $0.3 \mathrm{~cm}$ above the top of the electrodes, i.e. about $3 \mathrm{ml}$ electrolyte was used. The electrodes were allowed to soak for about $24 \mathrm{~h}$ prior to the start of the experiment. Thereafter, the cell was vacuumtreated to remove gas bubbles. (The cells were operated in the vented mode.)

The cells were assembled in two different ways:

Type A: The zinc electrode was placed between the two nickel oxide electrodes (cells 1 to 6 and 11 to 13, Table 1). In this configuration only one reference electrode was used, placed at the side of the cell. The relative position of the capillary hole in the side wall, with respect to the zinc electrode, is shown in Fig. 1A.

Type B: The zinc electrode was placed between the front cell wall and the nickel oxide electrode (consisting of two parallel plates) (cells 7-10, Table 1). One reference electrode, a, was mounted at the side of the electrode; three other reference electrodes, b, c, d, were placed along the front of the zinc electrode as indicated in Fig. 1B.

\section{Experimental procedure}

\subsection{Cycling experiments}

Batteries 1 to 10 (Table 1) were subjected to charge-discharge cycles at constant current, i.e. $200 \mathrm{~mA}$ for cells 1-6 (assembly type A) and $100 \mathrm{~mA}$ for cells 7-10 (assembly type B). Since zinc is utilized at two sides for cells $1-6$ and only at one side for cells $7-10$, this implies the same current density for all cells, i.e. $7.3 \mathrm{~mA} \mathrm{~cm}^{-2}$. An

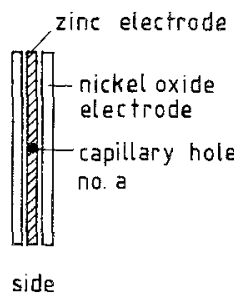

A

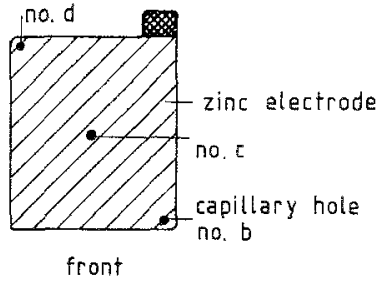

B
Fig. 1. Relative position of the capillary holes with respect to the zinc electrode for the assembly types $A$ and $B$. (Type B also contains a capillary hole at position a, as for type $\mathrm{A}$.) 
automatic cycling device was constructed for these experiments which was capable of repeated charging and discharging of three test cells to preselected cut-off times and/or voltages. The rest time between the cycles was usually $\sim 30 \mathrm{~min}$. This device was used in conjunction with a power supply (Delta power supply E $030-1)$. The cell voltage $\left(E_{\text {cell }}\right)$ and the potential of the zinc electrode with respect to the $\mathrm{Hg} / \mathrm{HgO}$ reference electrodes ( $E_{\mathrm{Zn}, \mathrm{a}}$ to $\left.E_{\mathrm{Zn}, \mathrm{d}}\right)$ were monitored using high impedance converters $\left(10^{13} \Omega\right.$ between the recorder and the reference electrodes).

The zinc electrodes were charged with $0.5 \mathrm{~A} h$ (cells 1-6) and $0.3 \mathrm{Ah}$ (cells 7-10), which is $20-40 \%$ of the theoretical capacity of the zinc active material (as is usual in zinc battery charging) $[5,6]$. Less charge passed through the cell if the cell voltage reached the charging cut-off voltage of about $2.2 \mathrm{~V}$ beyond which hydrogen is formed. Here, the state-of-charge (SOC) is defined as being $100 \%$ with this predetermined amount of charge or if the cut-off voltage is reached. The cells were discharged until the cell voltage reached the discharging cut-off voltage of about $1.35 \mathrm{~V}$, corresponding with a sudden decline in the voltage-time curve. This state is defined here as the fully discharged state $(0 \%$ SOC). After the cycling experiments, the tested cells were dismantled and the zinc electrode was examined for shape change, both visually and by measuring the thickness at different places of the electrode.

\subsection{Porosity of the zinc electrode}

The mercury penetration method was used to measure the pore volume per gram $V_{\mathrm{p}}\left(\mathrm{cm}^{3} \mathrm{~g}^{-1}\right)$, and the pore size distribution of electrodes fabricated from Teflon-bonded zinc oxide and from a mix of Teflon-bonded zinc oxide and amalgamated zinc powder. These measurements were carried out at the zinc species material without a current collector. The porosity was then calculated using

$$
\varepsilon=\frac{V_{\mathrm{p}}}{V_{\mathrm{p}}+\underline{Q}^{-1}}
$$

in which $\varrho$ is the true density of active material $\left(\mathrm{g} \mathrm{cm}^{-3}\right)$. The porosity can also be calculated from

$$
\varepsilon=\frac{V_{\mathrm{p}}}{V_{\mathrm{t}}}
$$

in which $V_{\mathrm{t}}$ is the total volume per gram of material $\left(\mathrm{cm}^{3} \mathrm{~g}^{-1}\right), \quad V_{\mathrm{t}}$ is determined by the geometric surface area and the thickness, for which the average value was taken from thickness measurements at different places along the electrode surface.

\subsection{Impedance measurements}

The apparatus used for the impedance measurements incorporated a frequency response analyser (Solartron 1250), an electrochemical interface (Solartron 1186) and a microcomputer (HP 9816), which completely controlled the experiment. The set-up is shown in Fig. 2. Measurements were made at frequencies in the range $0.01 \mathrm{~Hz}$ to $10 \mathrm{kHz}$. The amplitude of the sinusoidal potential perturbation was $1 \mathrm{mV}$ (rms). The impedance measurements were carried out
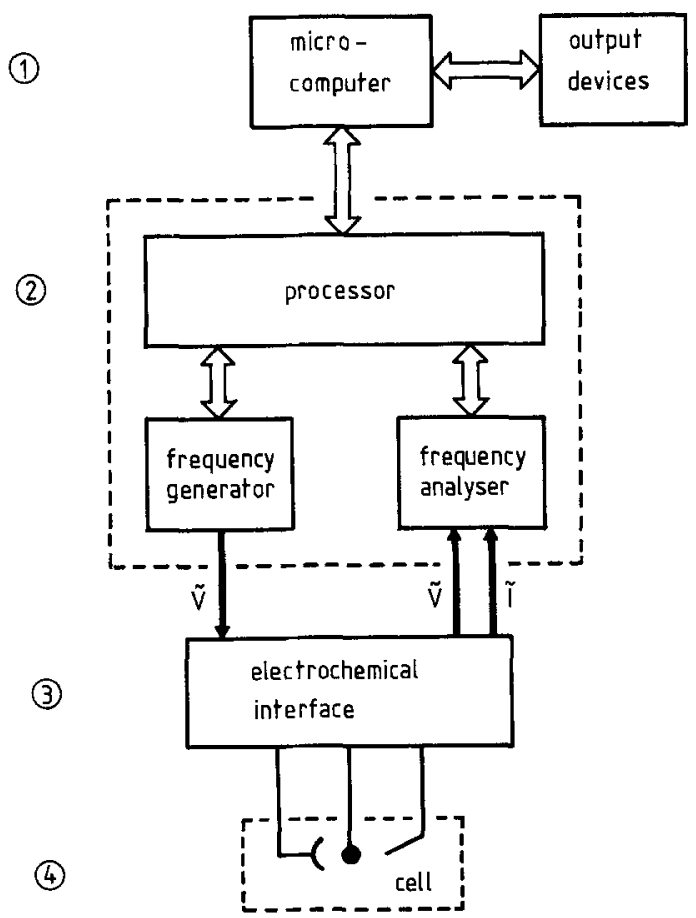

Fig. 2. System set-up for impedance measurements: 1. HP 9816 desktop computer and output devices; 2. Solartron 1250 frequency response analyser; 3 . Solartron 1186 electrochemical interface; 4 . three-electrode cell. 


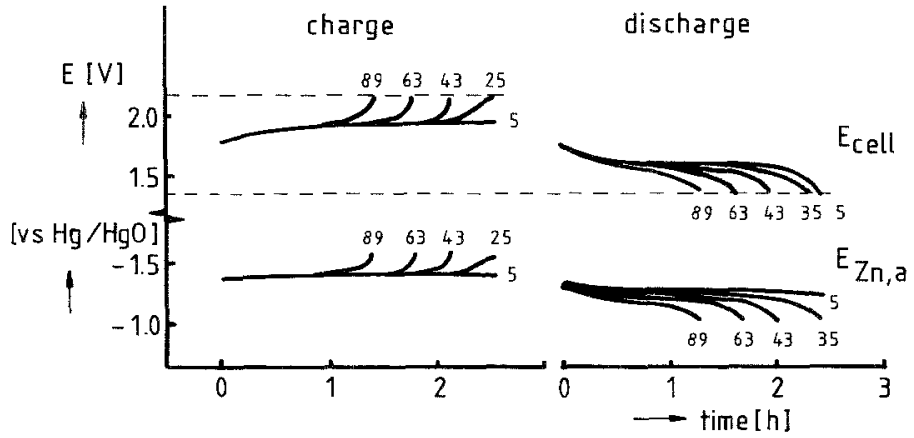

Fig. 3. $E_{\text {cell }}$ and $E_{Z n, a}$ versus time curves during charging and discharging of cell 1 at constant current of $200 \mathrm{~mA}$ for different cycle numbers. at zero current density as a function of SOC and the cycle number. It is to be noted that the standard resistor of the 'interface', which is required for the conversion of current to voltage, must be of the same order of magnitude as the resistance of the battery. A standard resistor of about $200 \mathrm{~m} \Omega$ was found to be necessary. Because of this low value, the results should be corrected for the internal resistance of the interface itself (about $110 \mathrm{~m} \Omega$ ).

\section{Results}

\subsection{Cycling experiments}

In Fig. 3, cell voltage $\left(E_{\text {cell }}\right)$ versus time and zinc potential $\left(E_{\mathrm{Zn}, \mathrm{a}}\right)$ versus time curves during charg- ing and discharging for cell 1 at a constant current of $200 \mathrm{~mA}$ are shown for different cycle numbers. During the first 35 cycles the cell can be charged with the predetermined amount of $0.5 \mathrm{~A} \mathrm{~h}$, but with increasing cycle number the cut-off voltage $(2.2 \mathrm{~V})$ is reached earlier so less charge is accepted by the cell. The zinc potential curves show a similar pattern as the cell voltage curves.

During discharge, $E_{\mathrm{Zn}, \mathrm{a}}$ remains constant for the first five cycles. On further cycling, a decrease of $E_{\mathrm{Zn}, \mathrm{a}}$ is observed at the end of discharge; after about 40 cycles a limit of $\sim 1.05 \mathrm{~V}$ (versus $\mathrm{Hg} / \mathrm{HgO}$ ) is reached at the $1.35 \mathrm{~V}$ cell cut-off voltage. Fig. 4 compares $E_{\text {cell }}$ and $E_{\mathrm{Zn} \text {,a }}$ at the end of the charge and discharge periods during cycling for cell 1 (no additive), cell 2 ( $\mathrm{PbO}$

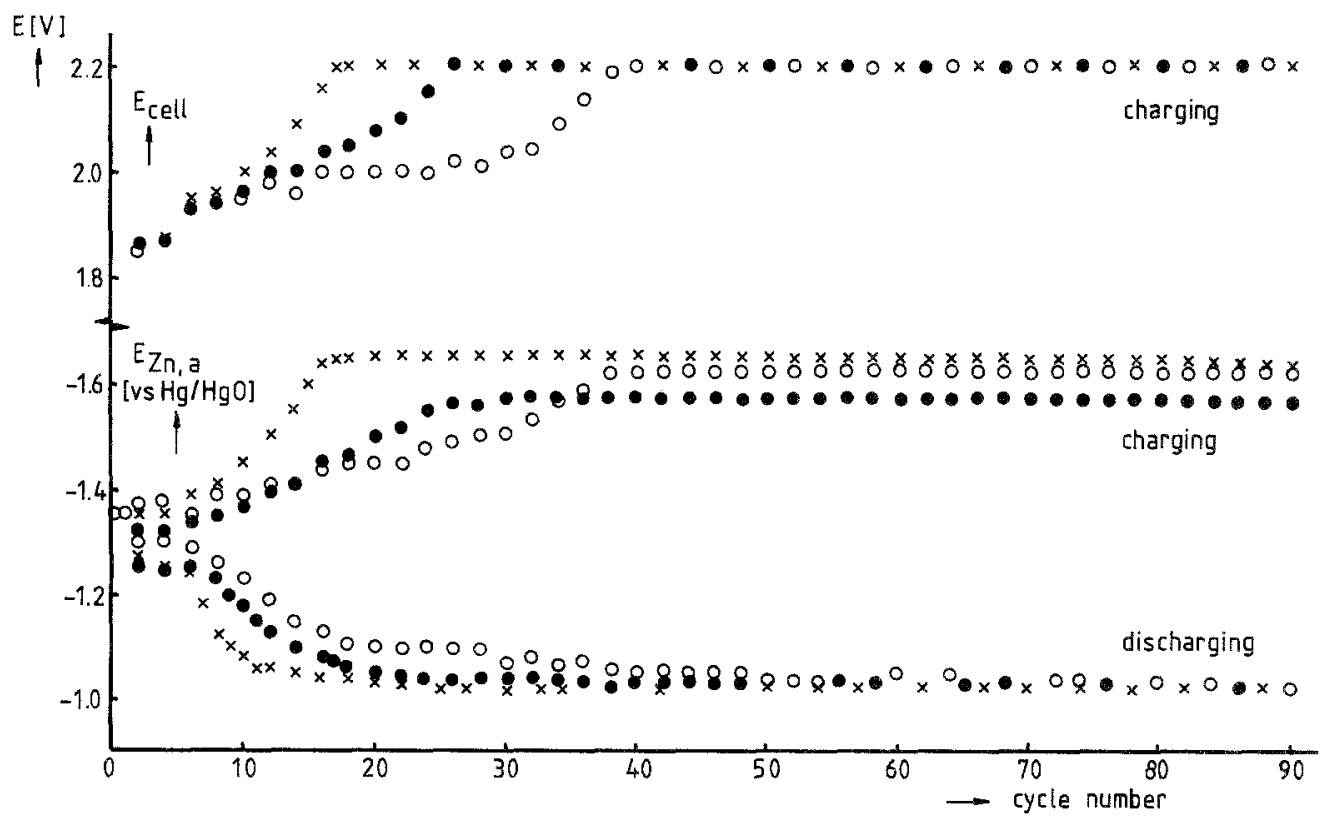

Fig. 4. $E_{\text {cell }}$ and $E_{\mathrm{Zn}, \mathrm{a}}$ of cells 1 to 3 at the end of the charge and discharge period as function of cycle number. O, cell 1; cell $2 ; x$, cell 3 . 


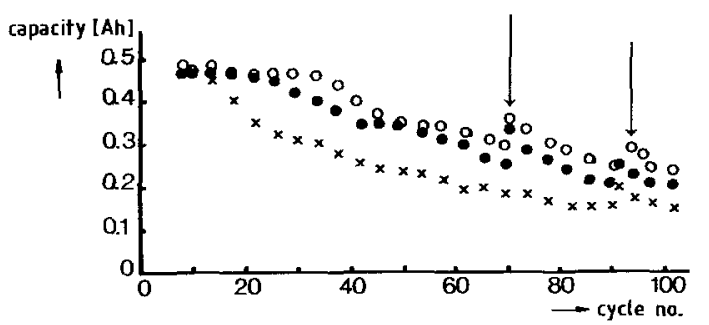

Fig. 5. Capacity of the cells 1 to 3 as function of cycle number. $O$, cell 1 ; $\bullet$, cell $2, x$, cell 3 ; arrows, rest period (64h).

additive) and cell 3 (HgO additive) (cf. Table 1). The cut-off voltage during charging is reached after 18 cycles in cell 3 , after 26 cycles in cell 2 and after 40 cycles in cell 1 . This pattern is also observed for $E_{\mathrm{Zn}, \mathrm{a}}$, which reaches a limit value of about $1.6 \mathrm{~V}$ (versus $\mathrm{Hg} / \mathrm{HgO}$ ) at the $2.2 \mathrm{~V}$ cell cut-off voltage. During discharging, $E_{\mathrm{Zn}, \mathrm{a}}$ levels off to $\sim 1.05 \mathrm{~V}$ (versus $\mathrm{Hg} / \mathrm{HgO}$ ), reached by cell 3 after about 15 cycles, by cell 2 after about 20 cycles and by cell 1 after about 40 cycles.

The charge efficiency, defined as the ratio of the charge output and the charge input, is about $95 \%$ for cell 3 and about $90 \%$ for cells 1 and 2 . The capacity (= charge output) of the three cells

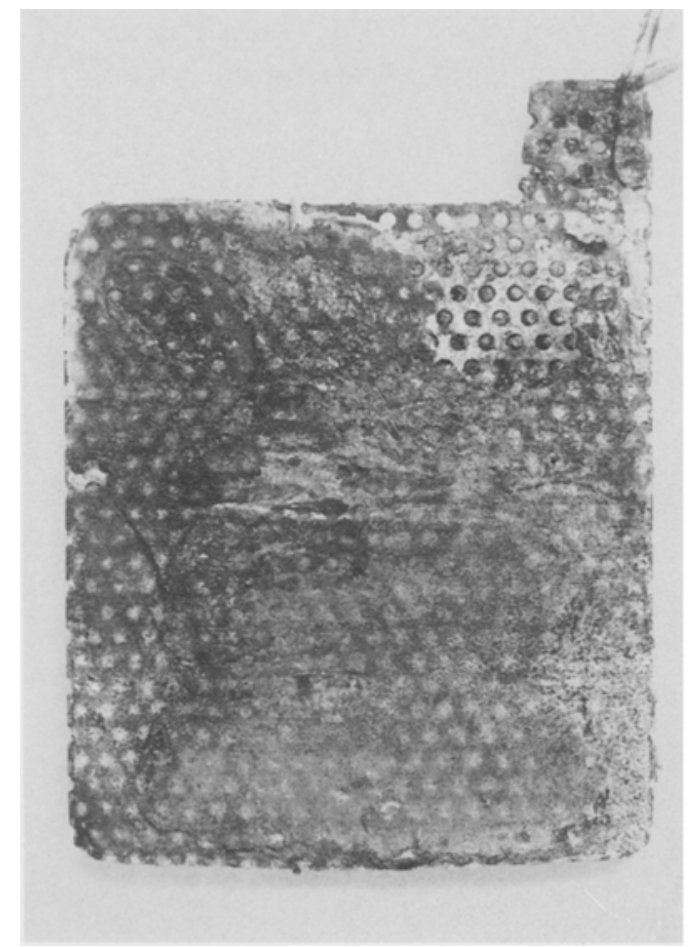

is plotted in Fig. 5. Initially, the capacities of the cells are constant, but with cycling the capacity decreases. However, a rest period $(64 \mathrm{~h})$ after 70 and 92 cycles, had a beneficial effect on the capacity of cell 1 and 2. Photographs of the zinc electrode from cell 2 after 104 cycles are shown in Fig. 6. In Fig. 7 the thickness distributions of the zinc electrodes of cells 1 to 3, measured at different locations along the surface are given. The amount of material is largest in the centre and at the bottom, showing unambiguously the shape change phenomenon. No significant differences between the three cells are observed. At the edges some active material is still present in a layer, which seems to be more teflonated than the material in the centre and at the bottom.

Cycling results for cell 5 , in which the zinc oxide is partially replaced by amalgamated zinc powder, are similar as depicted in Figs 3, 4, 6 and 7 . In Fig. 8 the capacity (= charge output) of these cells is plotted as a function of cycle number. The decrease, after an initially constant value, is much steeper than in cells 1 to 3 (Fig. 5). Already after $25-35$ cycles the capacities are

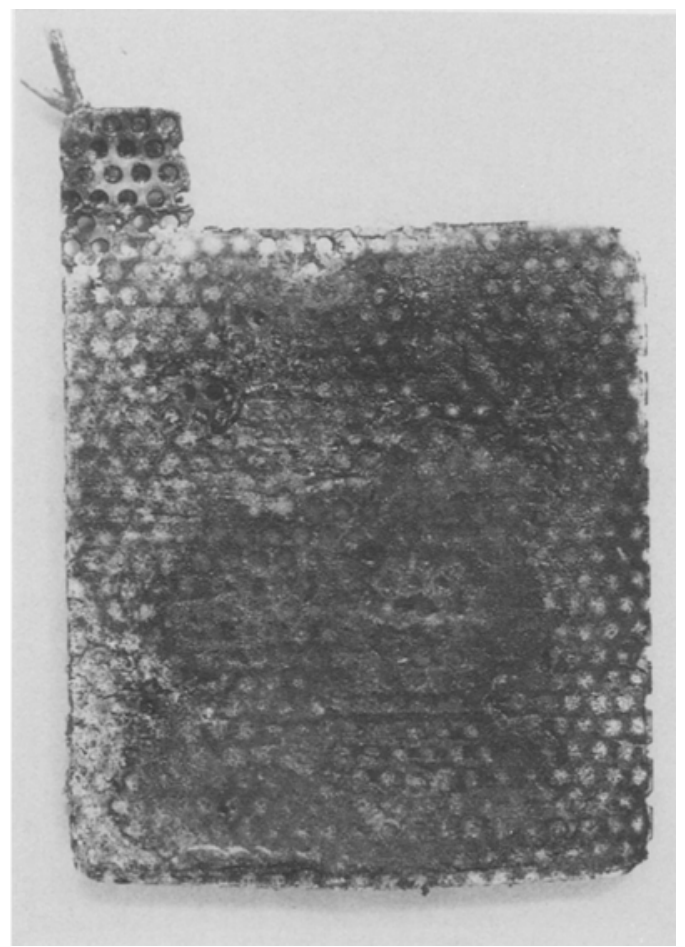

Fig. 6. Photographs of the zinc electrode (both sides) of cell 2 after 104 cycles. 


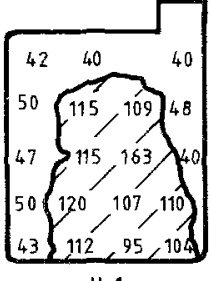

cell 1

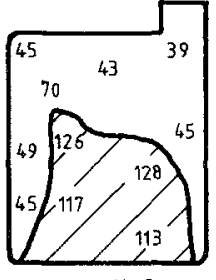

cell 2

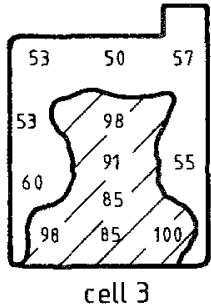

cell 3

Fig. 7. Thickness distributions (in $10^{-3} \mathrm{~cm}$ ) of the zinc electrode of cells 1 to 3 after 104 cycles as measured at different places along the surface.

reduced to $50 \%$ of the initial values. No significant differences between the three cells with the different percentage of mercury were found.

\subsection{Potential distribution}

The potential distribution over the surface of the zinc electrode was measured in the cells 7 to 9 using four reference electrodes, as indicated in Fig. $1\left(E_{\mathrm{Zn}, \mathrm{a}}\right.$ to $\left.E_{\mathrm{Zn}, \mathrm{d}}\right)$. Potential-time curves of cell 7 with $2 \% \mathrm{HgO}$ additive are shown in Fig. 9 for different cycle numbers, together with the cell voltage-time curves (Fig. 10). In Fig. 11 the potentials at the end of the charge and discharge period are plotted as a function of the cycle number. $E_{\mathrm{Zn}, \mathrm{a}}, E_{\mathrm{Zn}, \mathrm{b}}$ and $E_{\mathrm{Zn,d}}$ increase more gradually to a maximum value (about $1.8 \mathrm{~V}$ ) than $E_{\mathrm{Zn}, \mathrm{c}}$ (midst of plate), which suddenly increases to that value between cycles 52 and 55 . During discharging, differences between the potentials become clearer and different levellingoff values are reached. The capacity (initially constant) begins to decrease in the same cycle number $(52-55)$ at which $E_{\mathrm{Zn}, \mathrm{c}}$ strongly increases.

In cell 8 (also with $2 \% \mathrm{HgO}$ additive) the amount of active material of the zinc electrode is reduced to $1.5 \mathrm{~g}$. The cycle number at which $E_{\mathrm{Zn}, \mathrm{c}}$ strongly increases and the capacity begins to decline is now in the region $40-43$. Potential-

time curves at discharging of cell 9 (without the $\mathrm{HgO}$ additive) are different from those of cell 7 (with $2 \% \mathrm{HgO}$ additive): the increase with cycling of the potentials at the end of the charge period is much more gradual (Fig. 12). The potential distribution upon discharging is more uniform than in cell 7 and the highest overpotential is measured at the bottom edge $\left(E_{\mathrm{Zn}, \mathrm{b}}\right)$, contrary to cells 7 and 8 where the highest overpotential is measured at the top edge $\left(E_{\mathrm{Zn}, \mathrm{d}}\right)$.

\subsection{Porosity of zinc electrodes}

The porosity was determined for electrodes of the same composition as in cell 1 and 4 , i.e. a Teflon-bonded zinc oxide containing 1 part Teflon-bonded zinc oxide and 2 parts amalgamated zinc powder. The resulting data and the calculated porosites are given in Table 2. The calculated porosities are rather low compared with literature values $(0.5-0.8)$ [10-12].

\subsection{Impedance measurements}

Fig. 13 shows the impedance spectra of the zinc electrode, the nickel oxide electrode and the total cell in the discharged state after the first charge/discharge cycle of the battery. It can be seen that both electrodes contribute to the impedance of the total cell. Vectorial addition of the impedance of the two individual electrodes results in an impedance diagram which is nearly identical to the measured impedance of the total cell (the difference is smaller than $10 \mathrm{~m} \Omega$ in the frequency range $1-3000 \mathrm{~Hz}$ ). In the following, only the impedance of the zinc electrode will be considered. Fig. 14 shows the impedance of a fresh zinc oxide electrode (uncharged) and at various states-of-charge; in the uncharged state the impedance is capacitive.

During the first charging the impedance dia-

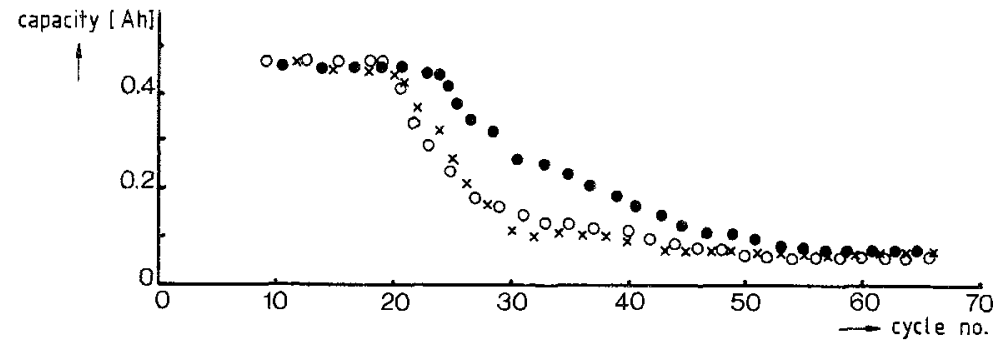

Fig. 8. Capacity of the cells 4 to 6 as function of cycle number. $O$, cell 4 ; cell $5 ; x$, cell 6 . 


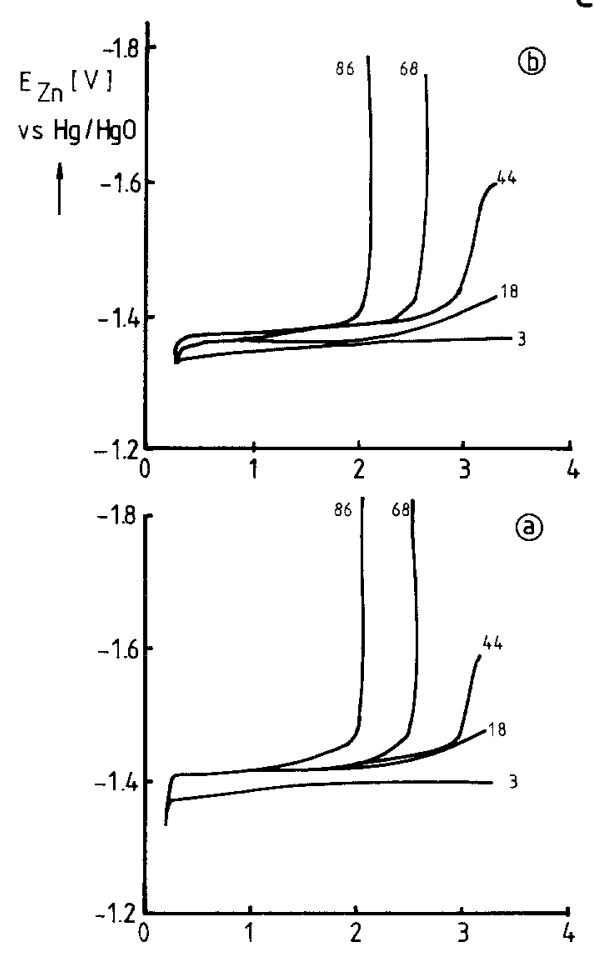

charge
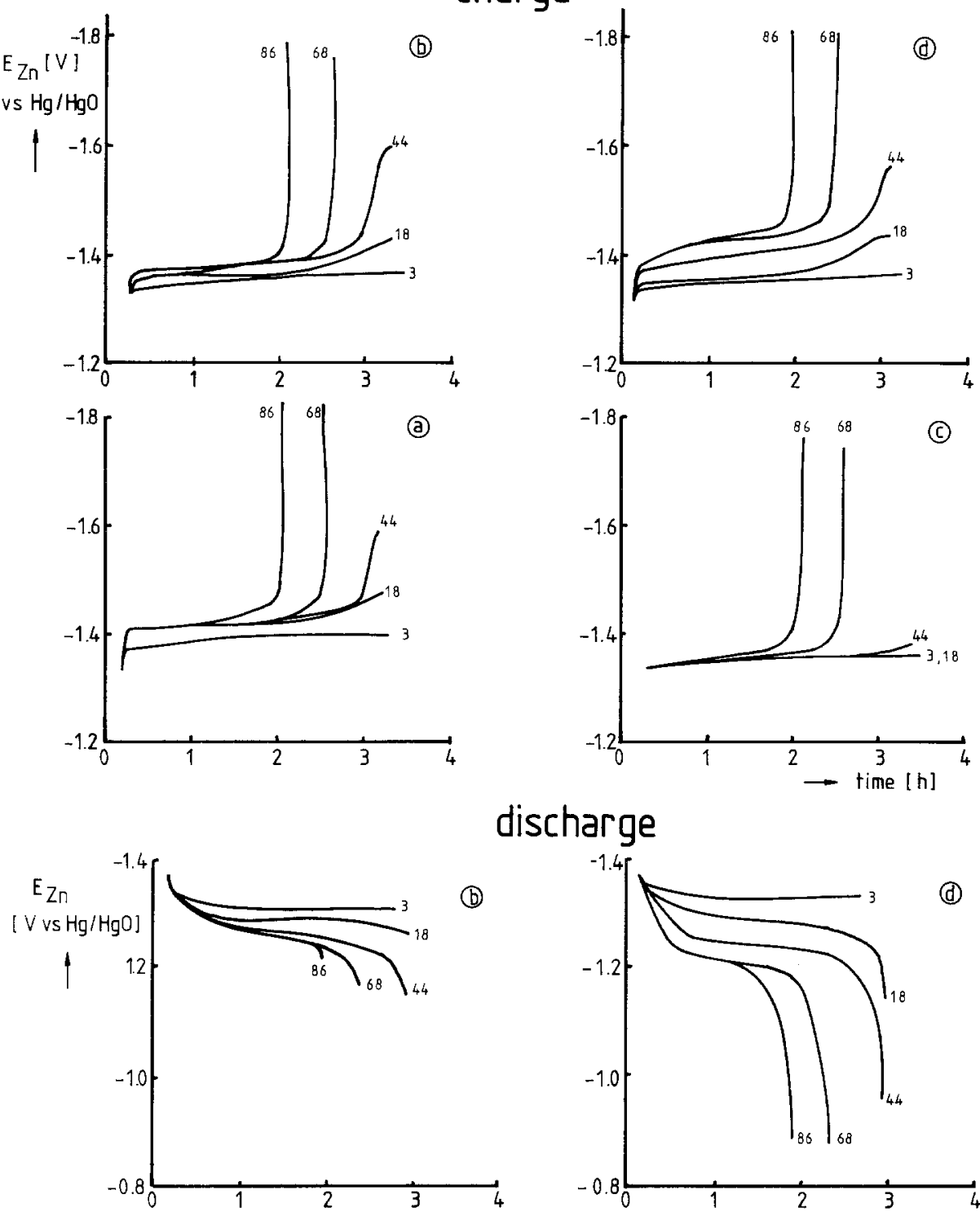

discharge
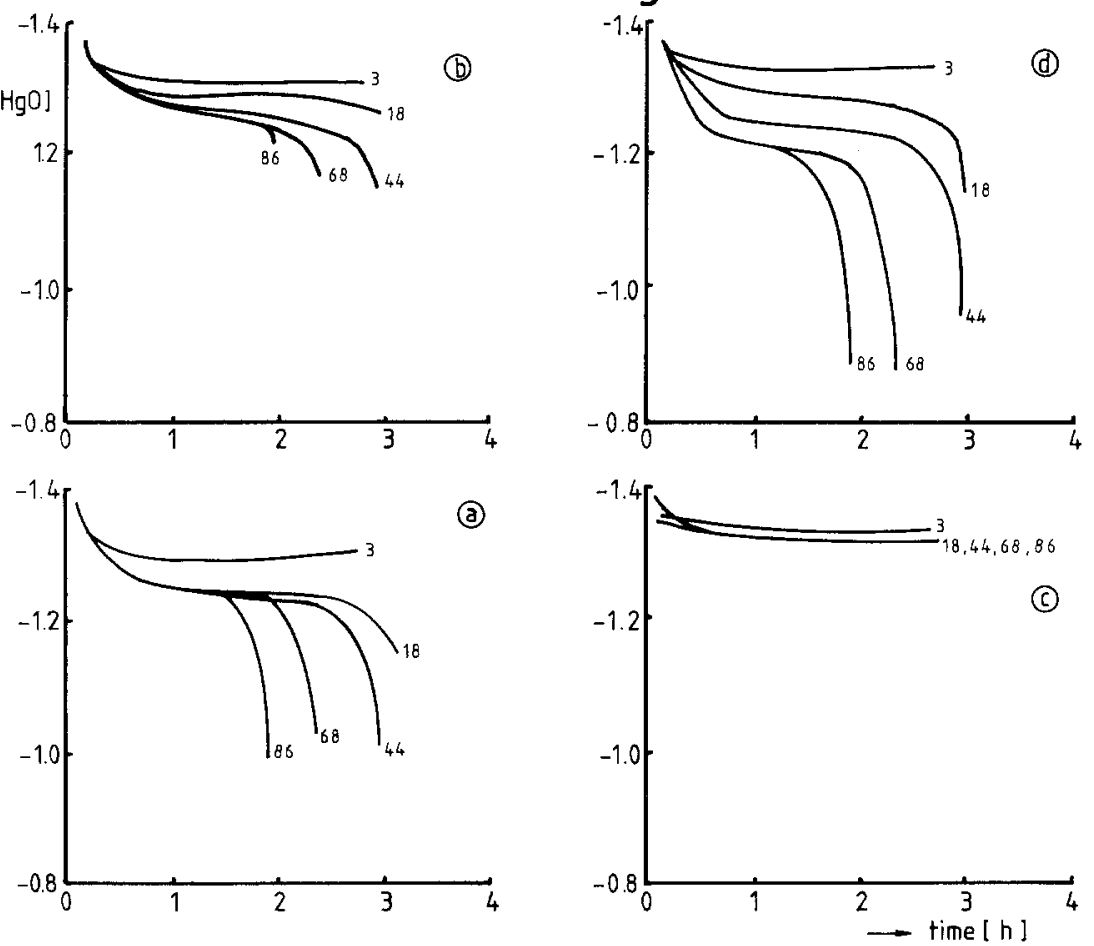

Fig. 9. $E_{\mathrm{Zn}, \mathrm{a}}$ to $E_{\mathrm{Zn}, \mathrm{d}}$ versus time curves during (A) charging and (B) discharging of cell 7 at constant current of $100 \mathrm{~mA}$ for different cycle numbers. a-d, position of reference electrodes (see Fig. 1B). 
Table 2. Comparison of two different types of zinc electrodes

\begin{tabular}{lcc}
\hline & $\begin{array}{l}\text { Teflon-bonded } \\
\text { zinc oxide }\end{array}$ & $\begin{array}{c}\text { Teflon-bonded zinc oxide } \\
\text { and amalgamated zinc powder }\end{array}$ \\
\hline Pore volume, $V_{\mathrm{p}}\left(\mathrm{cm}^{3} \mathrm{~g}^{-1}\right)$ & 0.115 & 0.067 \\
Mean pore radius, $R(\AA)$ & 260 & 320 \\
Surface area $\left(\mathrm{cm}^{2} \mathrm{~g}^{-1}\right)$ & $8.4 \times 10^{4}$ & $4 \times 10^{4}$ \\
True density, $\varrho\left(\mathrm{g} \mathrm{cm}^{-3}\right)^{*}$ & 5.3 & 6.8 \\
Total volume, $V_{\mathrm{t}}\left(\mathrm{cm}^{3} \mathrm{~g}^{-1}\right)$ & 0.32 & 0.2 \\
$\varepsilon$, with Equation 1 & 0.38 & 0.31 \\
$\varepsilon$, with Equation 2 & 0.36 & 0.31 \\
\hline * Calculated with $\varrho_{\mathrm{ZnO}}=5.6 \mathrm{~g} \mathrm{~cm}^{-3} ; \varrho_{\mathrm{Teflon}} \simeq 2 \mathrm{~g} \mathrm{~cm}^{-3}$. \\
$\varrho_{\mathrm{Zn}}=7.1 \mathrm{~g} \mathrm{~cm}^{-3} ; \varrho_{\mathrm{Hg}}=13.6 \mathrm{~g} \mathrm{~cm}^{-3}$.
\end{tabular}

gram changes considerably: the capacitive character decreases and in the fully charged state (about $0.50 \mathrm{Ah}$ ) a curve appears which is characteristic for kinetic and mass transport controlled processes. For a flat electrode the Warburg impedance should be a straight line at an angle of $45 \%$. However, the angle is smaller than $45^{\circ}$, which points to the porous character of the zinc electrode [13]. During this first charging, the ohmic resistance of the electrolyte increases due to the formation of gas bubbles (hydrogen).

The effect of discharge is shown in Fig. 15. The impedance values become larger and more capacitive, but the diagram does not return to the value for the uncharged battery. Fig. 16 shows the effect of cycling for the zinc electrode

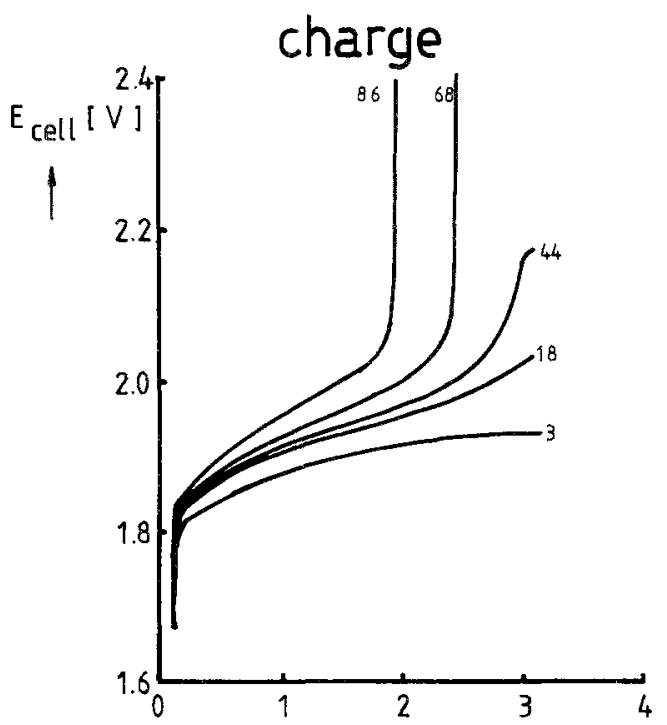

in the charged $(100 \%$ SOC) and discharged $(0 \%$ SOC) states. (All measurements are carried out after about $30 \mathrm{~min}$ rest, without degassing of the cell.) The impedance in the charged state is always smaller than in the discharged state, but the curves are not so well defined and so the specific information is hardly obtainable. Addition of $\mathrm{PbO}$ or $\mathrm{HgO}$ to the zinc oxide electrode has no appreciable influence on the impedance diagram. In order to see whether the occurrence of shape change can be detected with this technique, the impedance was measured as a function of the cycle number at different frequencies in charged and discharged state for three cells containing a zinc oxide electrode, a zinc oxide electrode with $\mathrm{PbO}$ additive and an

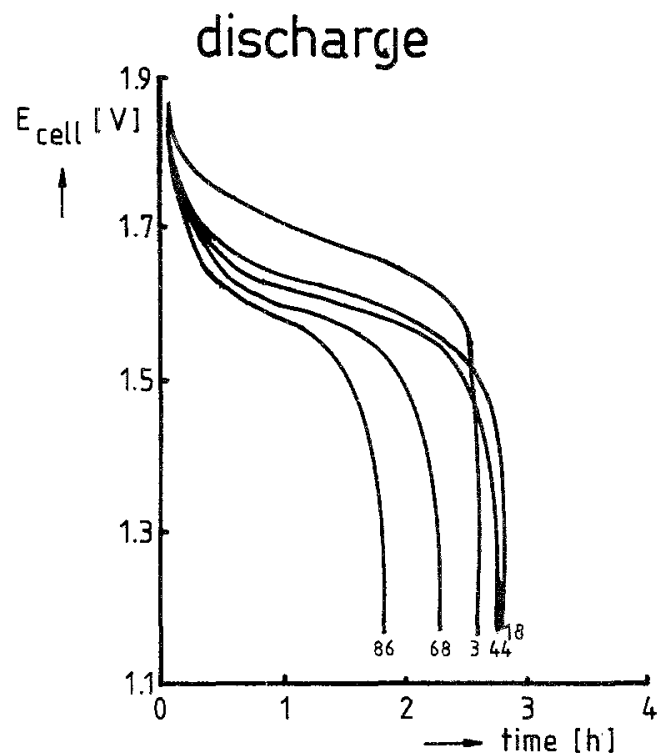

Fig. 10. $E_{\text {celi }}$ versus time curves during charging and discharging of cell 7 at constant current of $100 \mathrm{~mA}$ for different cycle numbers. 


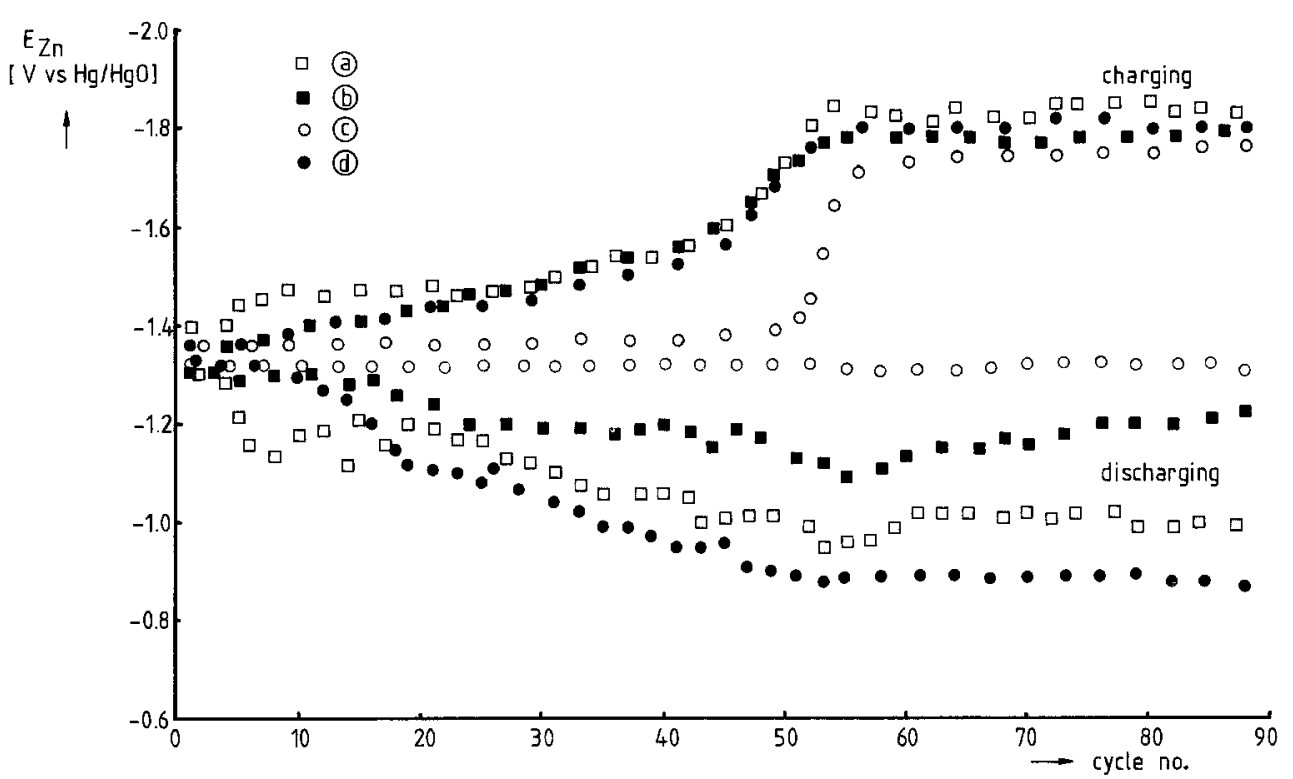

Fig. 11. $E_{\mathrm{Zn}, \mathrm{a}}$ to $E_{\mathrm{Zn}, \mathrm{d}}$ of cell 7 at the end of the charge and discharge period as function of cycle number. a-d, position of reference electrodes (see Fig. 1B).

electrode with $\mathrm{HgO}$ additive, respectively. After 104 cycles the cells were taken apart and shape change could be visibly observed in all three cells. It would be expected that shape change should result in a decrease of surface area, so that in all three cells this decrease should be reflected in the impedance data. However, no significant change of the impedance of the charged or of the discharged zinc electrode could be detected.

\section{Discussion}

While uncharged nickel oxide electrodes were used in cells 1 to 9 , the charging curves indicate that, initially, the cells can be loaded with the predetermined charge. Hence, the nickel oxide electrode is not capacity limiting and neither, initially, is the zinc electrode. By observation and comparison of Fig. 4 with Fig. 5, it appears that $E_{\mathrm{cell}}$ and $\left|E_{\mathrm{Zn}, \mathrm{a}}\right|$ increase with cycling at the

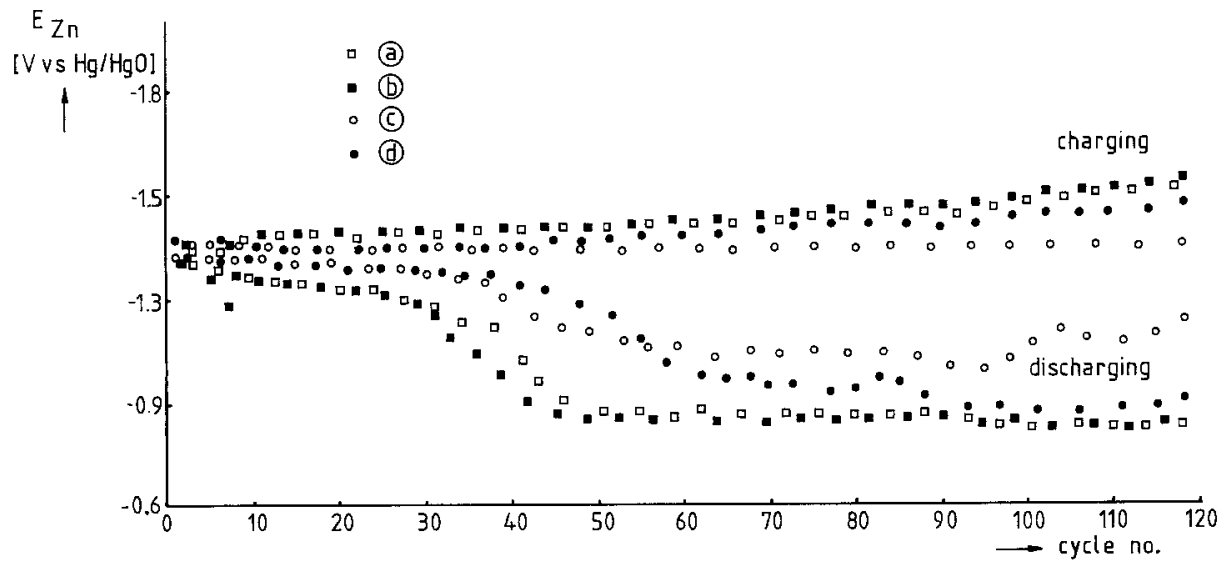

Fig. 12. $E_{\mathrm{Zn}, \mathrm{a}}$ to $E_{\mathrm{Zn}, \mathrm{d}}$ of cell 9 at the end of the charge and discharge period as function of cycle number. a-d, position of reference electrodes (see Fig. 1B). 


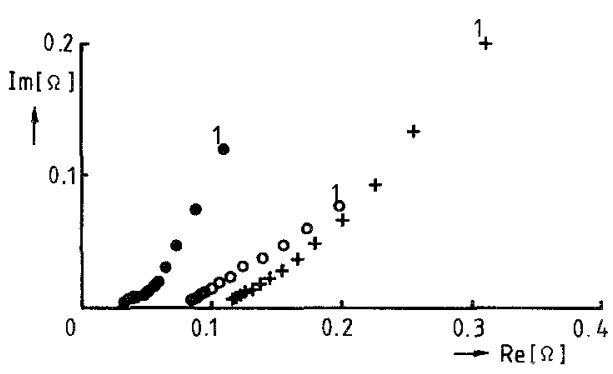

Fig. 13. Impedance spectra of nickel oxide-zinc battery after the first charge-discharge cycle. $\bullet$, zinc electrode; $O$, nickel oxide electrode; + , total cell. Frequency range, $1-5000 \mathrm{~Hz}$ (multiplication factor, 2).

end of the charge period and that the cut-off voltage and the maximum value of $E_{\mathrm{Zn}, \mathrm{a}}$ are reached at the same cycle that marks the start of the capacity decline of the cell. It follows from the charge efficiency data that, in a cycle, more zinc oxide is reduced during charging than zinc is oxidized in the subsequent discharge. With each following cycle the amount of reducible zinc oxide decreases and finally it becomes exhausted, so that the zinc electrode cannot be charged further. This effect was calculated for the amalgamated zinc electrodes (cells 3 to 8 ), where the rate of self-discharge is low.

In Table 3 the total amount of the differences between charge input and charge output of all cycles up to the start of capacity decline is given in column 5 ; column 7 gives the sum of column 5 and the charge input of the subsequent charge period (column 6). The theoretical capacities of the zinc oxide electrode (column 3) are in good agreement with the calculated sums. Therefore, it is concluded that the decrease

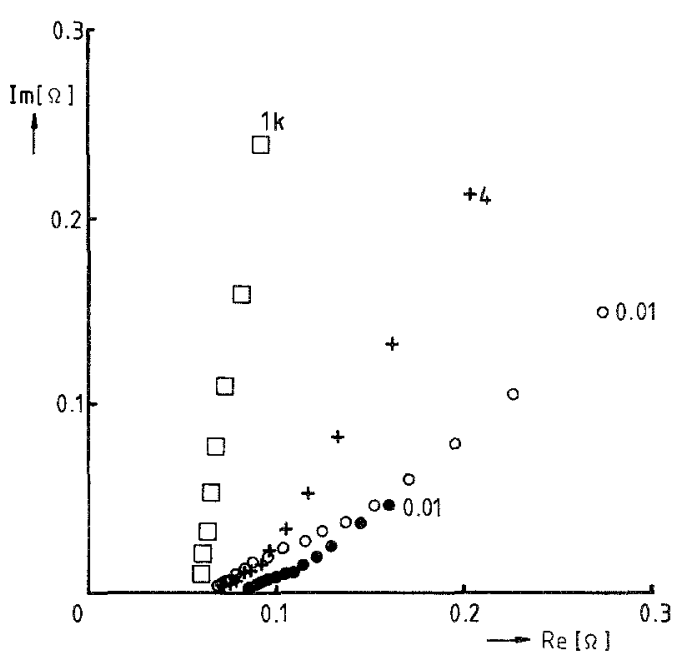

Fig. 14. Effect of the first discharge on the impedance spectrum of the zinc electrode. $\square$, uncharged (SOC 0\%), start frequency $1 \mathrm{kHz}$;,$+ 0.015 \mathrm{Ah}$ (SOC $3 \%$ ), start frequency $4 \mathrm{~Hz} ; 0,0.075 \mathrm{~A} \mathrm{~h}$ (SOC $14 \%$ ), start frequency $0.01 \mathrm{~Hz} ;$ $0.50 \mathrm{~A} \mathrm{~h}$ (SOC $100 \%$ ), start frequency $0.01 \mathrm{~Hz}$. Points indicate data at successive frequencies with multiplication by 2 .

of the capacity and the increase of the zinc overpotential during charging are caused by exhaustion of the active zinc oxide material. In cells with non-amalgamated zinc electrodes, considerable self-discharge occurs with the result that more active zinc oxide material is present than in amalgamated electrodes. This is demonstrated by the shift of the start of capacity decline to a higher cycle number (Fig. 5), and also by the more gradual increase of the cathodic zinc overpotentials (Fig. 12). During discharging of cells 1 to 9 it can be deduced from Figs 4 and 11 , that at the beginning of cycling ( $1-10$ cycles) the nickel oxide electrode is the capacity-limiting

Table 3. The theoretical capacity, the total amount of the differences between charge input and output up to the capacity decrease, and the charge input in the subsequent charge period for different cells

\begin{tabular}{lllllll}
\hline$(1)$ & $(2)$ & $(3)$ & $(4)$ & $(5)$ & $(6)$ & $(7)$ \\
\hline $\begin{array}{l}\text { Cell } \\
n o .\end{array}$ & $\begin{array}{l}\text { Amount of } \\
\mathrm{ZnO}(\mathrm{g})\end{array}$ & $\begin{array}{l}\text { Theoretical } \\
\text { capacity } \\
(\mathrm{A} h)\end{array}$ & $\begin{array}{l}\text { Cycles before } \\
\text { capacity } \\
\text { decrease }\end{array}$ & $\sum_{\mathrm{i}=1}^{\mathrm{n}}\left(\mathrm{A} \mathrm{h}_{\mathrm{in}}-\mathrm{A} \mathrm{h}_{\text {out }}\right)$ & $\begin{array}{l}\text { Charge input, } \\
\text { subsequent } \\
\text { charge period } \\
(\mathrm{A} h)\end{array}$ & $\begin{array}{l}\text { Sum } \\
(A h)\end{array}$ \\
\hline 3 & 2.0 & 1.3 & 18 & 0.67 & 0.43 & 1.10 \\
4 & 1.0 & 0.65 & 23 & 0.32 & 0.32 & 0.64 \\
5 & 1.0 & 0.65 & 24 & 0.22 & 0.45 & 0.67 \\
6 & 1.0 & 0.65 & 22 & 0.22 & 0.45 & 0.64 \\
7 & 2.0 & 1.3 & 54 & 1.10 & 0.30 & 1.55 \\
8 & 1.5 & 1.0 & 43 & 0.84 & & 1.14 \\
\hline
\end{tabular}




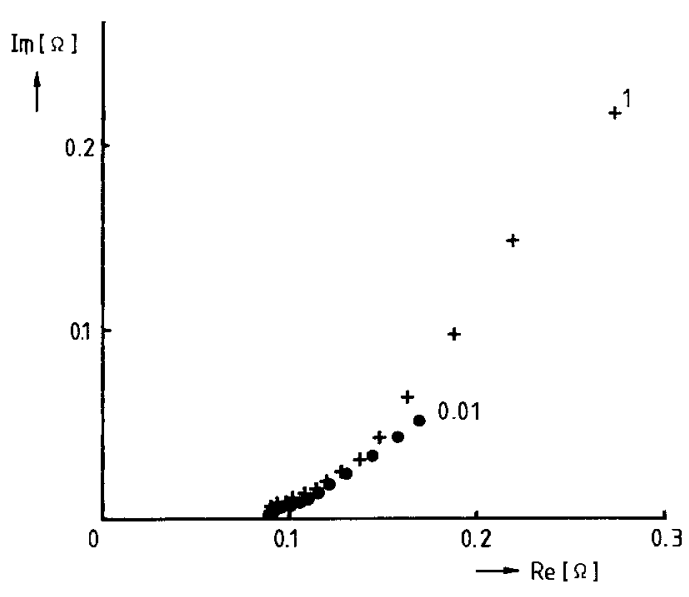

Fig. 15. Effect of the first discharge on the impedance spectrum of the zinc electrode. $0.50 \mathrm{Ah}$ (SOC 100\%), start frequency $0.01 \mathrm{~Hz}$; + , discharged (SOC $0 \%$ ), start frequency $1 \mathrm{~Hz}$. Points indicate data at successive frequencies with multiplication by 2 .

factor. With cycling, the zinc electrode gradually becomes the limiting electrode, as can be seen from the increasing anodic overpotential. Possible causes of the increase are:

(a) passivation of the zinc electrode by thin film formation [14, 15]

(b) plugging of the pores of the electrode by insoluble reaction products $[16,17]$

(c) depletion of electrolyte $[16,17]$.

A further point of interest is the much steeper decrease in capacity with cycling of cells 4,5 and 6 (Fig. 8) compared to cell 3 (Fig. 5). The difference in porosity between the two types of zinc electrode is thought to be responsible for this effect: the porosity $(\varepsilon)$ of the zinc electrodes in cells 4 to 6 is $\sim 0.31$, and $\sim 0.37$ in cell 3 (which in this respect can be compared with the zinc

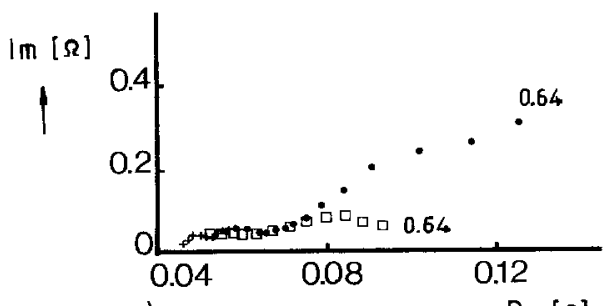

a) electrode in cell 1), implying a smaller surface area of the zinc electrode in cells 4 to 6 and hence a smaller degree of availability of the active material on discharging. Therefore the use of amalgamated zinc powder for fabrication of the zinc electrode does not have a beneficial effect on the cycling behaviour, though the rate of selfdischarge seems to be lower than with the other type of amalgamated zinc electrodes.

In principal, differences in overpotential over the surface of the zinc electrode can be attributed to:

(a) differences in local current density (as a result of the actual current distribution)

(b) variations in the zincate concentration at various points at the electrode

(c) local passivation phenomena.

The current distribution is determined by many factors. With no polarization at the electrodes the primary current distribution is operative [18]; this is determined by the geometry of the electrodes, the electrolyte and the separator. Due to activation and concentration polarization, the actual current distribution will be more uniform. The magnitudes of the effects of these polarizations are dependent on the ratios of the kinetic, respectively the mass transport resistance and the ohmic resistance. If only the primary current distribution is operative, then the current is highest at the periphery and no differences would be expected between charging and discharging. As result of polarization phenomena at the electrode, the actual current distribution varies continuously during charging and discharging with cycling.

From the potential distribution measure-

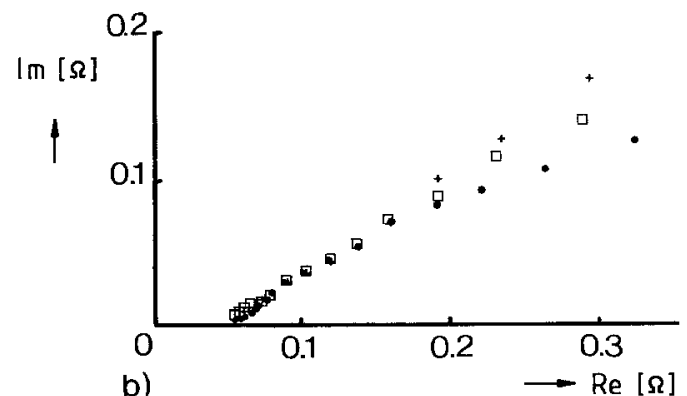

b)

Fig. 16. Effect of cycling on impedance spectra. (a) Charged state: frequency range $0.64-10 \mathrm{kHz}$ (multiplication factor, 2). + , cycle $13 ; \square$, cycle $31 ; \bullet$, cycle 75 . (b) Discharged state: frequency range $0.16-10 \mathrm{kHz}$ (multiplication factor, 2 ). + , cycle $12 ; \square$, cycle $31 ; \bullet$, cycle 75 . 
ments of cell 7 (with $\mathrm{HgO}$ additive) and cell 9 (without additive), it can be seen that for both cells the potential distribution was more uniform during the charge than during the discharge period. The distribution of the end potentials shows the same tendency (Figs 11,12 ).

After dismantling the cells, shape change could be clearly observed in all cells. This is tentatively explained as follows. If it is assumed that places with higher overpotentials correspond to places with greater current densities, then it follows that in cells 7 and 9 the current density in the periphery is larger than in the centre and that the current distribution is more uniform during charging than during discharging. Zincate is consumed in the charge period and produced in the discharge period. Therefore, the difference in current distribution will, during discharging, result in a concentration gradient of zincate along the surface in the direction of the centre, which is more negative than the same gradient in the direction of the periphery during charging. Hence, a net movement of zincate to the centre is expected as a result of one cycle. So the material redistribution, and thus the shape change, can be explained by diffusion of zincate along the surface caused by non-uniform current distributions. Local passivation could also contribute to potential differences along the electrode, but this would not result in zincate transport.

According to McBreen [9], differences in current distribution during charge and discharge lead to the formation of a concentration cell. This concept, however, cannot explain the material redistribution, because the greater differences in anodic overpotentials compared to the cathode overpotentials should lead to a net effect of dissolution of zinc in the centre and deposition in the periphery.

There was no distinct difference in the appearance of the different electrodes after dismantling the cell; therefore, the influence of additives on the rate of shape change could not be established. However, the higher rate of shape change, which is generally found for amalgamated zinc electrodes [1], could be explained by the more non-uniform potential distribution on discharging of the amalgamated electrode (cell 7, Fig. 11) compared to the non-amalgamated electrode (cell 9, Fig. 12); this would lead to a higher rate of material redistribution on discharging.

A mechanism of shape change based on nonuniform current distributions is not completely satisfactory, because it does not explain the accumulation of material at the bottom of the electrode upon cycling. The mechanism based on convective downward flows by (electro)osmotic pumping of the membrane separator [8] does explain shape change in the $y$-direction (see Fig. 17), but fails to explain shape change in the $z$-direction. Therefore, shape change seems to be caused by a combination of both these effects. Moreover, it is found that the capacity decline of the cells as a result of cycling is greater than expected by the observed reduction in geometric surface area. Redistribution of the active material in the $x$-direction leads to densification and this is thought to be responsible for the extra capacity decline.

\section{Conclusions}

1. Different types of zinc electrode were cycled. Shape change was observed in all cases and no distinct difference between the zinc electrodes with and without the $\mathrm{HgO}$ and $\mathrm{PbO}$ additive was observed. The change in porosity of the zinc electrodes, due to the incorporation of amalgamated zinc powder, is thought to be responsible for the steeper capacity decline with cycling.

2. The increase of the zinc overpotential during charge is caused by exhaustion of the

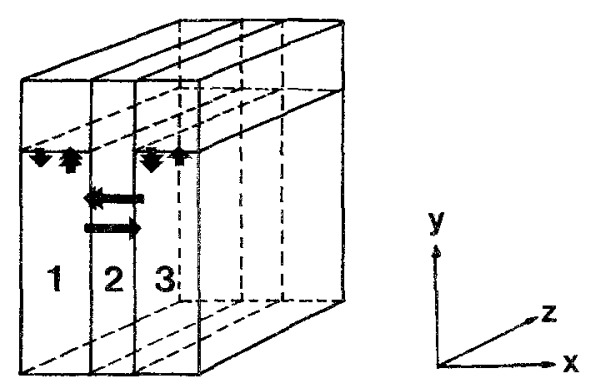

Fig. 17. Schematic view of the convective flows in the accumulator, $(\rightarrow)$ during charging; $(\rightarrow)$ during discharging; 1 , zinc compartment; 2 , membrane separator; 3 , nickel compartment. 
active zinc oxide material. After a number of cycles the zinc electrode has become the limiting electrode during discharge.

3. The potential distribution along the surface was assumed to correspond to the current distribution; this was then found to be non-uniform and led to a concentration gradient of zincate. The material redistribution, and thus the shape change, was tentatively explained by diffusion of zincate along the surface.

4. The impedance technique appears not to be a suitable technique for monitoring the shape change of the zinc electrode. Only the imaginary part of the impedance of low frequencies might be used to discriminate between the charged and discharged state of the zinc electrodes.

\section{Acknowledgements}

Support for this work by ZWO, the Netherlands Organization for the Advancement of Pure Research, and NIVEE, the Netherlands Institute for Electroheating and Electrochemistry, is gratefully acknowledged. The authors wish to thank the group of Professor Scholten at the Department of Chemical Technology, University of Technology, Delft, for the porosity measurements.

\section{References}

[1] G. A. Dalin, in 'Zinc-Silver Oxide Batteries' (edited by A. Fleischer and J. J. Lander), John Wiley, New York (1971) p. 87.

[2] O. Wagner and A. Himy, in 'Proceedings 27th Power Sources Symposium', PSC Publications Committee, Red Bank, NJ (1976) p. 135.

[3] A. Himy and O. Wagner, in 'Proceedings 28th Power Sources Symposium', PSC Publications Committee, Red Bank, NJ (1978) p. 167.

[4] J. A. Keralla and J. J. Lander, Electrochem. Tech. 6 (1968) 202.

[5] J. McBreen and E. Gannon, Electrochim. Acta 26 (1981) 1439.

[6] Idem, J. Electrochem. Soc. 130 (1983) 1980.

[7] J. McBreen, E. Gannon, D. T. Chin and R. Sethi, ibid. 130 (1983) 1641.

[8] K. W. Choi, D. N. Bennion and J. Newman, ibid. 123 (1976) 1616.

[9] J. McBreen, ibid. 119 (1972) 1620.

[10] T. S. Chang, Y. Y. Wang and C. C. Wan, J. Power Sources 10 (1983) 167.

[11] C. M. Shepherd and H. C. Langelan, J. Electrochem. Soc. 109 (1962) 657.

[12] Idem, ibid. 114 (1967) 8.

[13] R. de Levie, in 'Advances in Electrochemistry and Electrochemical Engineering, Vol. 6' (edited by P. Delahay), John Wiley, New York (1967) p. 329.

[14] Z. Nagy and J. O'M. Bockris, J. Electrochem. Soc. 119 (1972) 1129.

[15] R. W. Powers, ibid. 118 (1971) 685.

[16] W. G. Sunu and D. N. Bennion, ibid. 127 (1980) 2007.

[17] Idem, ibid. 127 (1980) 2017.

[18] H. E. Haring and W. Blum, Trans Electrochem. Soc. 44 (1923) 313 